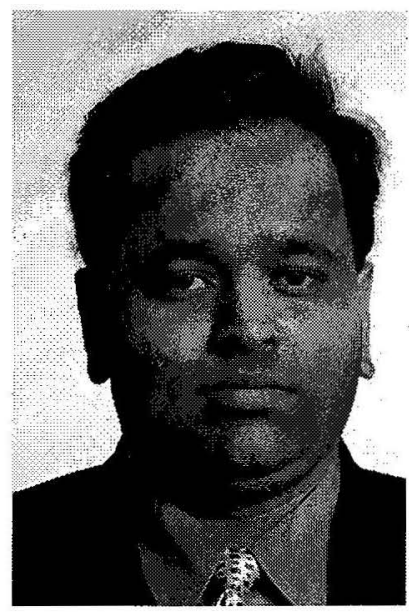

\title{
HUMAN CAPITAL \\ FORMATION AND \\ EMPLOYABILITY IN AN \\ INFORMATION ECONOMY: \\ A STUDY OF NEW \\ ZEALAND'S ICT SECTOR
}

\author{
Ashish Malik \\ School Of Management \\ The Open Polytechnic Of New Zealand
}

\begin{abstract}
Human capital formation is vital in furthering the employability of a nation's workforce. Employability in a networked and information society has undergone a paradigm shift. The key participants in the labour market- employers, employees, trade unions and the government have to proactively address various issues emerging at the global level by assessing its implications for them at macro and micro levels and by furthering human capital formation so as to maintain the employability of their workforce. This paper presents the trends emerging at global levels, the extent to which they are reflected in OECD countries and in New Zealand, with a specific focus on its ICT (Information and Communications Technology) sector. It further discusses the dilemma faced by different players in contributing in furthering human capital formation and employability. Secondary data pertaining to emerging trends on human capital and employability in the ICT sector is analysed from various government agencies and international organisations. Although there is some strength in the present system in terms of industry training provided in New Zealand, there are few areas of investment for human capital and some firm level practices which affect employability and human capital formation in future.
\end{abstract}

\section{Introduction}

This paper presents the concerns for employability and human capital formation in a knowledge economy with a specific focus on New Zealand's ICT (Information and Communications Technology) sector. It discusses the main trends in employability and human capital formation, and to what extent these are reflected in OECD countries and in New Zealand. The ICT sector is one of the high growth sectors in New Zealand, both in terms of its revenue and employment generation potential, and also affects the levels of employment and work in other sectors (ITAA, 2000, Ministry of Economic Development, 2002). Data on employment trends is analysed from World Employment Reports (WER) 199899 \& 2001, Organisation for Economic Cooperation and Development (OECD) statistics of member countries, Ministry of Economic Development, Ministry of Education, and New Zealand Census 1996 and 2001. In light of the above it discusses the implications and various policy initiatives taken by the government and industry in dealing with human capital formation at the national level and suggests possible measures in dealing with the issues of employability and human capital formation in the ICT sector.

\section{Global Trends in Human Capital formation and Employability}

Continuous investment in human capital results in higher growth and productivity and consequently higher earnings, this has been acknowledged since Adam Smith and more recently in the development literature since the 1960s (Shultz, 1961;Becker, 1964; Mincer, 1974), prior to this the neo-classical theory of growth focused on the tangible or physical aspects of capital accumulation as the key drivers of economic growth (Solow, 1956, 1957 and Swan, 1956) and other studies suggest reasons for the rising role played by intangible human capital formation (Abramovitz and David, 1973, 1996). Later in the 1980s there was a wave of new-growth theories or the endogenous growth theorists who suggested that accumulation in human capital has externality-inducing effects on an individual's productivity and that human capital accumulation is the main source of growth for nations (Lucas, 1988, 1993), also it is the main input for both 'the use of ideas and production of ideas' (Romer, 1990,1993). In the early 1990 s the focus shifted to the other activities pursued by skilled labour e.g. innovation and its diffusion in the economy, mainly classified as, innovation for improving the existing quality of goods and creating a variety of new products and production 
processes (Romer, 1990; Young, 1991 and Aghion and Howitt, 1992). Availability of high-end skills in an economy's human capital base is essential for its competitiveness and overall well-being, education and vocational training play an important role in this, as, according to a recent study, which studied output per worker and the educational attainment for 111 countries over a 30 year period (1960-1990), using within country changes in education and productivity, "finds that a oneyear increase in the average years of schooling for a country's workforce raises output per worker between five and fifteen percent (Topel,1998).

Employability is a concept that is different from job security. "Employability, or employment security, means being qualified for currently available work, whether with a present employer or elsewhere. It means maintaining essential knowledge and competence in a present job while gaining new knowledge and competence that will keep the worker employable as job requirements change, whereas job security means simply that rules and regulations are in place to ensure that a worker will always have a job within a given company (Sheckley, Lamdin and Keeton, 1993: 4-5).”

There is an increasing concern the world over for investment in human capital, creating skills necessary for a knowledge economy, and the fact that economic, social and cultural growth has increased for those countries that have made a planned effort in increasing their quantity and quality of human capital. We will briefly examine the key trends in employment as identified by International Labour Organisation (ILO), in the World Employment Report (WER) 2001. According to the WER, out of a total 3 billion in the global workforce nearly $25 \%$ are underemployed (ILO, 1999a: 1). At the end of the year 2000 , nearly 160 million were fully unemployed, of these 160 million most were first time job seekers and 50 million were from industrialized countries. Although there will be a slowdown in the global labour force participation rates in the next decade, there are still another 460 million people who will join the global workforce, and majority, nearly $67 \%$ will be from Asia, $3 \%$ from Europe and still smaller percentage from Africa (ILO, 2001a: 1).

Among the other trends emerging, there is a marked growth of non-standard employment, more women are joining the workforce and there is a considerable growth in the number of self-employed. Part-time work has tended to increase as a percentage of total employment. Between 1990 and 1999 it increased from $13 \%$ to $16 \%$ in the European Union, $13 \%$ to $15 \%$ in Europe as a whole, and from $14 \%$ to $16 \%$ in all OECD member countries (ILO, 2001b: 17). Analysis of OECD data for selected countries is given below in Table1, which shows how the percentage of part-time employment and self-employment has increased as a percentage of total employment.

There are strong trends in labour force migration; those who have high ICT or other high end skills are migrating from lower wage levels in developing countries towards competitive wage levels offered in developed countries. It is partly due to their ability to seek work outside their existing labour markets as they posses these marketable skills, which are in acute shortage in developed countries, and partly because of the inability of the developed countries to generate and retain these skills in adequate numbers. There is an increase in the number of foreignborn in the labour force as a percentage of total workforce in most OECD member countries are for example Australia employing 24.6\%, Canada 18.2\%, USA $11.7 \%$, Germany $9.1 \%$ and France 5.8\% (OECD, 2001: 16-17). The above is a gross under estimate of the situation as it does not cover any data on the number of illegal migrants, the estimated number for which is around 500,000 and 300,000 per annum for European Union and USA respectively (The Economist, 2000), The market for highly skilled workers will become even more integrated in the coming decades, and increased return to highly skilled people might continue to favour spatial concentration and movement of skills. This trend gains its strength from the fact that most of the developed and industrialized economies are faced with an ageing and shrinking or static population, the education system is inadequately supporting the growth of high-tech skills needed for a knowledge economy, and the slow speed of intervention from government and the industry to resolve this rather political issue. The ratio of those 65 years and above as a percentage of the population in such countries is set to rise higher as shown in the Table 2 .

There are many member countries of OECD who earn a major share of their GDP through investments in technology and knowledge. Enhancing the value of human capital is now considered critical for growth of GDP. The OECD has concluded (somewhat cautiously) that there is a "new economy" and that higher skills are a factor that has been driving growth for a long while and continued to do so over the 1990s. Most of the countries that were successful in raising their growth of GDP per capita over the 1990 s experienced a parallel rise in education levels among the employed and the workingage population at large. On the other hand there is a rise in informal economy (which represents low wages, self employment, outsourcing, domestic work and existence of micro enterprises), and a study in Latin American countries shows a negative correlation between per capita GDP and the share of employment in an informal economy (ILO, 1999b: 23-24).

\section{Moving towards a Knowledge Economy}

The implication of the knowledge economy is that there is no alternative way to prosperity than to make learning and knowledge -creation of prime importance. There are different kinds of knowledge e.g. 'tacit knowledge', which is gained from experience, rather than that instilled by formal education and training, and 'codified knowledge' - one that is gained through structured and formal education. In the knowledge economy 'tacit knowledge' is as important as formal, codified, structured and explicit knowledge. "ICT plays an essential role in 
the "codification" of knowledge. The latter implies that knowledge is transformed into 'information' which can either be embodied in new material goods (machines, new consumer goods) or be easily transmitted through information infrastructures. One important kind of tacit knowledge is skills. The most important impact of new ICT is that they move the border between tacit and codified knowledge. They make it technically possible and economically attractive to codify kinds of knowledge, which so far have remained in a tacit form (Soete, 2001: 3)."

There is a growing evidence of a 'digital divide' in industrialised countries, $5 \%$ of the world's population are internet users- and $88 \%$ of them are in industrialised countries (World Bank Group, 2000: 14). The term 'digital divide' describes the gap between those that have access and make use of information technology particularly personal computers (PCs) and Internet connectivity - and those who do not. There is a considerable evidence to suggest that in addition to the existence of a technological gap, the digital divide may exacerbate socio -economic divisions within the society. There is an increasing debate whether the increase in unemployment rates is due to the introduction of ICT; this has shown some interesting results. Although there have be significant job losses due to skills obsolescence and automation, there is an evidence of increase in employment with the growth in and usage of ICT in some countries (ILO, 2001c: 117-125). The usage of ICT has also lead to spatial distribution in employment and high polarization of skills. There is a decreasing access to training and developing skills for those already in the workforce and specifically so for part-time and casual workers (Austen, 1995; VandenHuevel and Wooden, 1999: 3 ;OECD, 2000: 4)

The use of ICT is seen as a catalyst in developing knowledge and increasing the access to it. ICT are the enablers of change. They do not themselves create transformations in society. ICTs are best regarded as the facilitators of knowledge creation in innovative societies (OECD, 1996: 5-6). Furthermore with increase in globalisation of trade, ICT is often seen as a catalyst for business growth. Finland and Ireland are economies similar in social and economic structure to New Zealand, and have prospered significantly by investing in high-end technologies and ICT. Finland's agrarian population has come down from $70 \%$ to $6 \%$, and its high-tech industry as a percentage of the total GNP has jumped five fold in ten years (ITAG, 1999a: 9). Ireland's success from a virtually bankrupt economy into one of the fastest growing economies has also come about with appropriate policy decisions taken by the government, by investing heavily in education, especially technical education. Today, Ireland has software and electronics exports amounting to $40 \%$ of the total exports (ITAG, 1999b: $10)$.

\section{New Zealand's Experience:}

\section{The demographic trends of New Zealand's workforce}

New Zealand has experienced similar global trends and concerns in employability, for instance, Census 2001 shows an increase in the number of part-time workers in the labour force, female participation rates in the workforce have increased and even more for those employed in part-time jobs. As on year ending March 2002 nearly $1,970,000$ persons were in the labour force, representing a labour force participation rate of $66.8 \%$, and nearly $1,04,000$ were unemployed. The unemployment rate for men has gone down from $5.5 \%$ in March 2001 to $5.2 \%$ in 2002 despite the increase in their labour force participation rate whereas the unemployment rate for women has marginally increased from $5.3 \%$ to $5.4 \%$ during the same period (Statistics New Zealand, 2002a). Comparing by ethnicity unemployment rates are the lowest for Europeans at $3.7 \%$, highest for Maori at $12.9 \%$, followed by $9.9 \%$ for Pacific Island people and $8.4 \%$ for others. The ageing population and workforce still remains a major concern for New Zealand, nearly 12 $\%$ of the total population are 65 years and above. The unemployment rate is high as well as on an increase for those in the 15-19 age group at $15.7 \%$ and for those in $20-24$ age group at $10.9 \%$. There is an increase in the number of foreign-born in our workforce and the population. Nearly, quarter million Asians are in the population besides people of other ethnicities, representing a high ethnic diversity in New Zealand's workforce. Although there is an overall growth in employment, and an increase in the number of women working part-time, the number of men in part-time employment has gone down (Statistics New Zealand, 2002b).

\section{New Zealand and its ICT sector}

New Zealand is one of the several developed countries rapidly evolving into a 'knowledge society'. There has already been a sharp rise of knowledge industries like biotechnology, genetic engineering, software development and ICT services etc. The number of those employed in the traditional primary and secondary sector have fallen, and there is a consistent growth in numbers of those employed in the tertiary sector, particularly in knowledge industries. The ICT sector is the largest among them and it directly or indirectly supports the growth of other knowledge industries; hence the need for ICT sector's performance in New Zealand is considered to be important. Rt.Hon. Helen Clark, Prime Minister of New Zealand, expressed, " Prosperous economies in the $21^{\text {st }}$ century will be those driven by knowledge, skill, technology, innovation, productivity, and entrepreneurship. New Zealand won't prosper on low levels of achievement. We need a more educated and 
skilled New Zealander's for our country ... What is more, the pace of technological change will require that base to be continually up skilled and renewed"(Clark, 2001).

At a macro level, the ICT sector in New Zealand is increasing in importance, both in terms of contribution to GDP and its employment generation potential. The total value of exports for March 2000 for Computer hardware and parts amounted to NZ\$ 369 millions, \$ 113 million for software, $\$ 251$ million for Computer \& education services and \$232 million for communication services. The ICT exports from New Zealand have grown at an average rate of $32 \%$ between 1994 and 2000. For the year ending 2000 , ICT represented $10.6 \%$ of the GDP and $2.8 \%$ of the country's total exports. The total value of New Zealand's ICT sector is valued at NZ\$ 11,133.3 million (Ministry of Economic Development, 2001a: 712; Statistics New Zealand, 1996). Census findings from 1996 and 2001 confirm its increasing presence in the labour market. In 1996, nearly 23,000 people approximately $1.5 \%$ of New Zealand's workforce was employed in ICT occupations but not in the ICT sector (Statistics New Zealand, 1996), the numbers for 2001 are expected to be much higher for this segment of the workforce. The total number of persons employed in ITrelated occupations has increased by $76 \%$ between 1996 and 2001 . There were a total of 33,705 people employed in IT-related occupations in 2001. The main area of growth was in computer application engineer roles, which more than doubled during the same period. There has been a $49 \%$ increase in information technology management occupations, $7 \%$ increase is registered in computer technicians and controller occupations, but there was a marginal decline in the number of computer programmers (Statistics New Zealand, 2002c: 32), which is an area of concern. In terms of employment, the biggest employer was computer consultancy services employing 15,635 , showing a growth rate of $251 \%$ from 1993 to 2000 . The participation rates of males were higher than females in all age groups. As per the data women were at the entry-level jobs e.g. data entry operators etc as opposed to the managerial and other high skills jobs occupied by men. In terms of employment (excluding data entry) in IT occupations by ethnicity, there is a clear trend, with Europeans representing $85 \%$ of employment in ICT, Maori 6\%, Pacific Island people 2 $\%$, people of Asian decent $7 \%$ and others $1 \%$ (Ministry of Economic Development, 2001b: 19-20).

\section{Skills development for the knowledge economy: Education, Industry training and Research}

It is now lack of investment in human capital, not physical capital that prevents poor countries from catching up with the rich ones. Educational attainment and public spending on education are positively correlated to economic growth (Barro and Sala-i-Martin, 1995). For New Zealand to be successful as a knowledge economy, it has to generate cutting edge technology skills necessary and a need to build awareness and competencies across a host of other high technology disciplines. Given the ageing population and the fact that over $80 \%$ of the people who will be in the workforce over the next decade are in the workforce already, and the number of young people aged 15-24 in the labour force is projected to increase by only 40,000 in the next decade (Ministry of Commerce, 1999), there is a need to increase the skills through further investment in education, industry training and research and development initiatives.

An analysis of New Zealand's education system reveals that 49,385 qualifications were gained on the National Qualifications Framework (NQF) ever since its inception in 1991 to $2000,16,845$ or $34.10 \%$ were in 'Computing and information Technology' and 'Engineering \& Technology' (Ministry of Education, 2000). The recent Census 2001 findings show an increase in the number of graduates pursuing post-school Information technology qualifications at 24,012 up from 12,144 in 1996 (Statistics New Zealand, 2002d: 48). The numbers of graduates in these disciplines are still less considering the number of qualifications registered in computing and engineering on the NQF. The problem is aggravated further with the country loosing its highly skilled workers to overseas labour markets. New Zealand also lags behind most of other member OECD countries in the number mathematics and computer science graduates produced in a year. The percentage of tertiary graduates by science and technology field in mathematics and computer science is $0.8 \%$ as compared to the OECD average of $3.9 \%(\mathrm{OECD}, 1998)$. The limited number of science and technology graduates has to some extent influenced decisions of major multinational companies to divert their resources and investments to other countries that can provide them with competitive number of skilled workers and the necessary infrastructure. Clearly, the current education system is inadequate in generating the required numbers, and the level of awareness for ICT and other technologies needs to be improved from the school level. Since the Maori population is more youthful than the pakehas, and will have an increased labour-force participation rate in the future, increasing their educational attainment rates and developing their skills is necessary for improving their labour force participation rates.

A skilled workforce is vital to New Zealand's economic growth, standard of living and international competitiveness. While the passage of the Industry Training Act in 1992 has resulted in a number of positive developments, New Zealand still does not have the kind of integrated skills and employment strategy that is required (Maharey, 2001: 2). A quick review of the industry training system reveals that nearly 95,263 trainees were involved in industry training in March 2001 and this includes modern apprentices. Already 78,240 trainees have been registered under industry training as on 30 June 2002; all of these qualifications are linked to the NQF (Skill New Zealand, 2002). Education and off-the -job training is provided by universities, 
polytechnics and private training establishments. Government's present budget for 2002-03 is pegged at NZ\$ 87 million for Industry training, which has increased by NZ\$ 8 million from the previous year. Overall New Zealanders already invest substantially in workplace training. According to OECD figures covering 1994-95, $47 \%$ of New Zealander's in employment participate in job-related training, this is well above the OECD average of $34 \%$; the need however is for more technical skills training, necessary for a knowledge economy. It is clear if we look at the Electro-technology ITO, which works with the electrical, electronics, telecommunications, and security and offender management sectors and has 32 national qualifications registered on the NQF and it arranges training and promotes careers in these industries. As at December 2000, this ITO managed training for 3300 trainees, the number accounts for a small proportion i.e. $5.2 \%$ of the total trainees under the industry training. There are other structured training inputs needed in the service sector, such as call centers (have only recently started offering formal qualifications and training) are becoming interested in making use of structured training, both as a service quality strategy and as a staff recruitment and retention strategy. (Department of Labour, 2001: 11).

Innovation in science and technology is often seen as an important contributor in building the quality and quantity of human capital necessary for knowledge economy, and even more importance is given to the speed of innovation considering the short life span of products and services. One way to measure innovation is to see the amount of expenditure incurred on Research and Development(R\&D) both by government and the business community. "No nation can 'free-ride' on the world scientific system. In order to participate in a system, a nation ...needs capability to understand the knowledge produced by others and that understanding can only be developed through performing research (Salter and Ben, 1999)." Recent US research shows that government R\&D spending on IT sector led to the most explosive economic growth the world has ever known (PITAC, 1999). New Zealand's knowledge base is relatively small and the statistics reveal it spends relatively less in R\&D. New Zealand spends only $1.1 \%$ of its GDP as compared to $2.2 \%$ for the OECD average, and has only $4.5 \mathrm{R} \& \mathrm{D}$ personnel per 1000 of the labour force (MoRST, 1999: 3;OECD, 2000: 72). Further, there is limited interaction between the government and business in aligning the areas of expenditure and investments. Government and Universities together account for $72.1 \%$ of the total expenditure on R\&D, and business only contributes $27.9 \%$. As compared to other OECD countries, business expenditure in $R \& D$ is in the range of $67.5 \%$, indicating a more focused and need based spread. Furthermore, although the share of investment in R\&D is on the rise, New Zealand spends only $11 \%$ of the total R\&D budget outlay in information and communication (MoRST, 1999: 4).

\section{Conclusion}

From the above discussion it is evident that firstly, there is need to increase investment and resources for education, $R \& D$, and workplace training. There are policy initiatives already in place such as the Tertiary Education Strategy 2002-2007, which embarks on, among other issues, on developing capability and capacity relating to knowledge and skills required for the knowledge economy. While the strategy provides for a long-term perspective in improving New Zealand's capability and capacity issues, the shortage of ICT skills can also be addressed in the short-term through a more integrated immigration policy. The present immigration policy of points system and the role of New Zealand Qualification Authority in this need to be integrated with the labour market requirements, else it may loose its credibility and thus attractiveness of New Zealand as a destination for migrants with high skills. Another source of attracting highly skilled personnel is by focusing on repatriation of New Zealand's highly skilled workers as can be seen in case of China, India and Vietnam who have not only gained from the return of their highly skilled workers by creating conducive conditions, but have also benefited from the additional foreign-exchange and the further investment and employment within the ICT sector. There is a need to further integrate the ICT sector's requirements with education, R\&D and immigration policies in order to bridge the gaps, and clearly 'lifelong learning' has to be adopted as the new mantra, first, at school and then at workplace.

Secondly, there is a tremendous potential for employment in IT-enabled services- both within the organizations and as an outsourcing opportunity. It is the fastest growing sector in providing employment in many developed and developing countries. Indian IT-enabled services registered an increase of 25,000 jobs in 2000-2001 totaling 70,000. The European Union is expected to employ 1.3 million people in call centers alone up from 670,000 in 2001(ILO, 2001d: 7). New Zealand has a well developed ICT infrastructure, a currency advantage as well as preferable time zones to tap the opportunities for such services e.g. call centers, medical transcription, database management, legal documentations, e-learning and training, media and entertainment. Although criticized by some for the cheap labour that call centers are characterized with, the median wage rate for an experienced call center employee is NZ\$ 32,900 and the entry level median salary is NZ\$25,900(Finsec, 2001: 1), this compares well with the median salary of NZ\$ 18,500 in New Zealand (Statistics New Zealand, 2002e: 1). This will also facilitate the expansion of basic ICT skills and development of further applications for the global market in this segment.

Thirdly, although no specific data is available for the ICT sector in New Zealand, what is of particular concern, is the increasing nature of non-standard employment, and the decreasing access to training and skills development for those who are employed in this category (Felstead, Ashton, and Green, 2001: 53-54;Campbell, 2001: 93-94). 
Employers, employees, unions and the policy makers must collaborate to reduce, if not eliminate, this decreasing access to training by covering various forms of non-standard employment for all in-house and external training opportunities. The employers should have incentives for increasing their training budgets in the form of tax benefits/rebates etc from the government. Unions will need to negotiate more of skill-based collective employment agreements, with a focus on continuous and lifelong learning, skills development, appropriate leave and spatial displacement provisions in order to maintain the employability of their members.

Innovative human resource management practices need to be actively applied to retain the existing base of highly skilled workforce; e.g. competitive remuneration and benefits, flexible work options, overseas sabbaticals and assignments, continuous investments in transferable and non-transferable skills, employee stock option plans, both in the domestic and overseas stock exchanges e.g. NASDAQ and NYSE. Nevertheless, the 'gap' and a 'digital divide' exists in our society which is gradually increasing, but the technology available to us provides with an opportunity to leapfrog and reduce the gaps, provided we are able to increase and improve on our existing skills base and pursue further integrated and proactive policies.

There is need for further research to be undertaken at a firm and individual level within the ICT sector to ascertain the factors that facilitate or hinder decisions of employers and individuals to invest in training for generic skills (transferable to other employers) and firm-specific skills (non-transferable). Also it is not clear whether certain high-commitment HRM activities can affect the investment decisions at a firm and /or individual level.

Table 1 OECD Statistics for select member countries on employment trends in 1999.

\begin{tabular}{|l|l|l|l|l|}
\hline Countries & $\begin{array}{l}\text { Unemployment } \\
\text { Rates \% }\end{array}$ & $\begin{array}{l}\text { Part-time } \\
\text { employment as a \% } \\
\text { of total employment }\end{array}$ & $\begin{array}{l}\text { Females in part time } \\
\text { employment as a \% } \\
\text { of total employment }\end{array}$ & $\begin{array}{l}\text { Self employment as } \\
\text { a } \\
\text { employment }\end{array}$ \\
\hline Australia & 7.0 & $26.1(2)$ & $68.9(2)$ & $14.5(2)$ \\
\hline Canada & 7.6 & 18.5 & 69.7 & 14.7 \\
\hline New Zealand & $5.4(1)$ & 23.0 & 73.3 & 20.1 \\
\hline U.K. & 6.0 & 23.0 & 79.6 & 11.7 \\
\hline USA & 4.2 & $13.3(3)$ & 68.4 & 7.5 \\
\hline
\end{tabular}

(1) For 2001(Statistics New Zealand, 2002)

(2) Actual hours worked

(3) Dependent employment.

Sources: Labour Force Statistics: 1979-1999 Paris: OECD Employment Outlook June 2000.

Table.2 Ageing: Population over 65 as a percentage of total population, 1980-2050

\begin{tabular}{|l|l|l|l|l|l|}
\hline Country Type/Years & 1980 & 2000 & 2010 & 2030 & 2050 \\
\hline World Total & 5.6 & 6.9 & 7.6 & 11.8 & 16.4 \\
\hline More Developed & 11.6 & 14.4 & 15.9 & 22.6 & 25.9 \\
\hline Less Developed & 4.1 & 5.1 & 5.8 & 9.9 & 15.0 \\
\hline Least Developed & 3.1 & 3.1 & 3.2 & 4.5 & 8.1 \\
\hline
\end{tabular}

Source: ILO World Report 2000(Geneva: ILO, 2000

\section{References}

Abramotvitz, Moses and Paul .A. David (1973), "Reinterpreting Economic Growth: Parables and Realities." American Economic Review, vol. 63 (2) , pp 428-439

Abramotvitz, Moses and Paul .A. David (1996), "Technological Change and the Rise of Intangible Investments: The U.S. Economy's Growth -Path in the Twentieth Century," in OECD, Employment and Growth in the Knowledge Based Economy, Paris and Washington D.C., pp 35-60

Aghion, Philippe and Peter Howitt (1992) , “ A Model of Growth through Creative Destruction," Econometrica, Vol. 60 (2), pp 323-51 
Austen, S (1995) The growth in part-time employment: Implications for Training Policy. Western Australia, Department of Training, Perth.

Barro. R. and Sala -I-Martin. X (1995) 'Economic Growth.' New York: McGraw Hill

Becker, G. 'Human Capital: A theoretical and empirical analysis' (Princeton , N.J., Princeton University Press, 1964.

Campbell, I. (2001) 'Casual Employees and the Training Deficit.' International Journal of Employment Studies Vol 9 No 1 pp 93-94

Clarke, Rt.Hon Helen (2001) Speech to Industry Training Federation Conference Wellington, 26 July 2001

Department Of Labour (2001) 'Skills for a Knowledge Economy: A Review of Industry Training in New Zealand' Wellington: Department of Labour p 11

Felstead, A, Ashton, D and Grant, F. (2001) 'Training, Skills and Non Standard Jobs in Britain.' International Journal of Employment Studies Vol. 9 No 1 pp 53-54

Finsec (2001) Archived call center news http://www.finsec.org.nz/callcentre archive.html accessed on 15 May 2002.

ITAA, 2000, Information Technology Association of America, 'Bridging the gap: Information technology skills for a new millennium.'

ITAG-Information Technology Advisory Group (1999a) 'The Knowledge Economy' Wellington: ITAG pp 9 Report also available on http://www.knowledge.gen.nz

ITAG-Information Technology Advisory Group (1999b) 'The Knowledge Economy' Wellington: ITAG pp 10 Report also available on http://www.knowledge.gen.nz

ILO (1999a) World Employment Report- 1998-99 'Employability In The Global Economy-How Training Matters.' Geneva: International Labour Office $p 1$

ILO (1999b) World Employment Report- 1998-99 'Employability In The Global Economy-How Training Matters.' Geneva: International Labour Office pp 23-24

ILO (2001a) World Employment Report -2001 'Life at work in the Information Economy.' Geneva: International Labour Office $\mathrm{p} 1$

ILO (2001b) World Employment Report -2001 'Life at work in the Information Economy.' Geneva: International Labour Office $\mathrm{p} 17$
ILO (2001c) World Employment Report -2001 'Life at work in the Information Economy.' Geneva: International Labour Office pp 117-125

ILO (2001d) World Employment Report -2001 'Life at work in the Information Economy.' Geneva: International Labour Office $\mathrm{p} 7$

Lucas, R., (1988) "On the mechanics of economic development", in Journal of Monetary Economics (Amsterdam), Vol.22, No.1, 1988, pp.3-22.

Lucas, R., (1993) "Making a Miracle", in econometrica (New Haven,Conn.), Vol .61, No.2, 1993

Maharey, Steve (2001) 'Skills for a Knowledge Economy: A Review of Industry Training in New Zealand.' Wellington: Department of Labour pp 2

Mincer, Jacob (1962), “ On-the-job-training: Costs, Returns and Some Implications," Journal of Political Economy, Vol.70 (5), pp 50-79

Ministry of Commerce, New Zealand (1999) 'The Social Impact of Information Technology: A briefing to the Minister for Information Technology' (Wellington, 17 December 1999)

Ministry of Economic Development (2001a) 'Statistics on Information Technology in New Zealand, 2001.' Wellington: Ministry of Economic Development, ITPG pp 7-12

Ministry of Economic Development (2001b) 'Statistics on Information Technology in New Zealand, 2001.' Wellington: Ministry of Economic Development, ITPG pp 19-20

Ministry of Education (2001) 'New Zealand's Tertiary Education Report: Profile and Trends.' Wellington: Ministry of Education

MoRST-Ministry of Research, Science, \& Technology (1999a) 'New Zealand's Research and Development Statistics 1997/98.' Wellington: MORST p 3

MoRST-Ministry of Research, Science, \& Technology (1999b) 'New Zealand's Research and Development Statistics 1997/98.' Wellington: MORST p 4

OECD (1996) 'Science, Technology and Industry Outlook 1996' Paris: OECD pp 5-6

OECD (1998) 'Education at a glance: OECD Indicators.' Paris: OECD

OECD (2000) 'Knowledge, work organisation and economic growth-an outline.' Paris: OECD pp 4

OECD (2001) 'OECD in Figures: Statistics on the Member Countries- 2001 ed.’ Paris: OECD pp 1617 
President's IT Advisory Committee- PITAC (1999) 'IT Research: Investing in Future.' Arlington, VA: National Coordination Office for Computing, Information and Communications.

Romer, Paul M. (1990) , "Endogenous Technological change," Journal Of Political Economy, Vol. 98 (5), pp S71-S102

Salter, AJ and Ben, RM (1999) 'The Economic benefits of publicly funded research: A critical Evaluation review of Research Policy.' (In Publication)

Sheckley, BG, Lamdin, L and Keeton, MT (1993). Employability in a high performance society

\section{Chicago: Council for Adult and Experiential Learning} pp 4-5

Shultz, T., (1961) "Investment in human capital", in American Economic Review (Nashville), March 1961, pp1-17

Statistics New Zealand (1996) 'Household Labour force Survey- Census 1996' Wellington: Statistics New Zealand

Statistics New Zealand, (2002a) as accessed on $13 / 09 / 2002$

http:/www.stats.govt.nz/domino/external/pasfull/p asfull.nsf/0/4c2567ef00247c6acc256c0f0001cda1/ \$FILE/alltabls.xls

Statistics New Zealand (2002b) 'Household Labour force Survey- Census 2001' Wellington: Statistics New Zealand

Statistics New Zealand (2002c) Information Technology Use in New Zealand: 2002: 32

Statistics New Zealand (2002d) Information Technology Use in New Zealand: 2002: 48
Statistics New Zealand (2002e) '2001 Census Snapshot 3- Work, Education and Income' Wellington: Statistics p 1

Skill New Zealand (2002) Vital Statistics archive as accessed on 13 September 2002 at www.skillnz.govt.nz/new/vitalstatistics.htm

Soete, L (2001) 'The impact of ICT on Employment: The new labour market challenge.' Background paper to the World Employment Report 2001'Life at work in the Information Economy.' Available in CR-ROM version of the report Geneva: ILO

Solow, Robert M, (1956), "A Contribution to the Theory of Economic Growth," Quarterly Journal of Economics, Vol. 70 (1), pp 65-94

Solow, Robert M, (1957), "Technical Change and the Aggregate Production Function," Review of Economics and Statistics, Vol. 39 (3) , pp 312-20

Swan, Trevor W. (1956), "Economic Growth and Capital Accumulation," Economic Record, Vol. 32 pp 334-61

The Economist, London 23 June 2000

Topel, T., (1998) Labour markets and economic growth, paper presented at -The society of Labour Economists, Third Annual Meeting, 1-12 May 1998, San Francisco

VandenHuevel, A and Wooden, M (1999), Casualisation and Outsourcing: Trends and Implications for work related training: 3 Adelaide: NCVER

World Bank Group (2000) 'The Networking Revolution: Opportunities and challenges for developing countries.' Washington, DC: Global Information and Communications Technologies Department $\mathrm{p} 14$ 